\title{
PALMYRAH PALM WINE 1: MICROBIAL AND BIOCHEMICAL CHANGES
}

\author{
R. KUMUTHINI CHRYSTOPHER AND K. THEIVENDIRARAJAH \\ Department of Botany, University of Jaffna, Jaffna, Sri Lanka.
}

(Date of receipt : 12 October 1986)

(Date of acceptance : 27 January 1988)

\begin{abstract}
The palmyrah paim wine, or 'toddy', is the spontaneously fermented sap of the young and mature inflorescences of both male and female palmyrah (Borassus flabellifer) palms. The alcohol content of naturally fermented palmyrah toddy was usually ranging between $5.2-5.6 \% \mathrm{v} / \mathrm{v}$. However, in spite of the lower sugar content in the sap, the toddy from matured female inflorescences contained higher percentages (an average of $6.5 \% \mathrm{v} / \mathrm{v}$ ) of alcohol and this increased efficiency of fermentation may be due to either the presence of fermentable substrates other than sugars or to the presence of yeast strains with superior fermentative ability. Studies reveal that the Saccbaromyces yeasts PY 1 and PY 10 were the best fermentors among those isolated from palmyrah toddy and the yeast Schizosaccharomyces pombe PY 7 produced alcohol to a similar extent, but after longer fermentation. It was also found that the efficiency of sucrose to alcohol conversion can be increased up to about $92 \%$ by aseptically inoculating Saccharomyces yeasts as a monoculture into unfermented sap.
\end{abstract}

\section{Introduction}

The main product of the palmyrah palm Borassus flabellifer is the sap extracted from the inflorescences by a process known as 'tapping'. This sap can be consumed either in an unfermented stage (sweet toddy/'neera') or in a fermented stage (wine/toddy) or it may be consumed in some processed form such as 'jaggery' or sugar candy.

The term 'fermentation' can be defined in general terms as an oxidoreduction process, where the terminal electron acceptors are organic compounds. Normally, sugars, in an intermediate oxidation state, fulfil this requirement.

The current method of fermentation of palmyrah sap is an uncontrolled spontaneous process, taking place in the collecting pot due to the accumulation and growth of wild yeasts from the air. As the same earthenware pot is used for several successive days for toddy or wine collection, its inner surface gets coated with a layer of yeasts and bacteria.

The fresh, unfermented sap obtained from the inflorescences of palmyrah palm contains $10-16.5 \% \mathrm{w} / \mathrm{v}$ sugar, mainly in the form of sucrose. 9 This sucrose initially undergoes hydrolysis to form glucose and 
fructose, due to the action of the enzyme 'invertase' located in the yeast cell wall close to the external surface. ${ }^{7}$ Glucose and fructose, transported into the yeast cells, undergo glycolysis via the Embden-Meyerhof-Parnas pathway ${ }^{2}$ resulting in the production of ethanol, carbon dioxide and energy. This fermented product is popularly known as 'toddy' or 'palm wine' and the component of interest in this product is ethanol.

The inorganic constituents of toddy samples have received less attention than have the organic components. Nevertheless, the minerals are of considerable significance in fermentation processes and many of them are of significance in human nutrition.?

'Toddy' contains a large quantity of wild yeasts and bacteria. The bulked toddy contains about $10^{7}-10^{8}$ cells of yeasts per $\mathrm{ml}$ of the sample. Yeasts belonging to the genus Saccharomyces (PY 1 and PY 10), Schizosaccharomyces (PY 7) and Kloeckera (PY 2) were isolated from the naturally fermented palmyrah palm wine. ${ }^{11}$ Most of the bacteria in the palmyrah toddy samples were identified as belonging to the genus Bacillus. ${ }^{10}$

As reported by Thirukanesan and Theivendirarajah ${ }^{12}$ the method of tapping a palmyrah palm varies with the sex of the palm and age of the inflorescence. In the present study, the average alcohol content in toddy samples obtained by different methods of tapping, viz., 'aripanai', 'vallupanai', 'thattupanai' and 'kaivetty' was determined. The fermenting abilities of the different yeasts (those previously isolated from naturally fermented palmyrah wine) and the changes in sugar and alcohol contents during the fermentation process were also studied.

\section{Materials and Methods}

\subsection{Collection of Materials and Preparation of Experimental Media}

\subsubsection{Fresh unfermented sap}

This was collected in sterile MacCartney bottles by holding the bottle at the tip of the inflorescence for about 3 minutes. The sample was immediately stored at $5^{\circ} \mathrm{C}$ or was heated in a boiling water bath for 15 minutes to inactivate the microorganisms which may have contaminated the sap. This sample was mainly used to determine the sugar content of unfermented sap.

\section{2:1.2 Sweet toddy}

Palmyrah sweet toddy was collected for 14 hours in earthenware pots; the inner surface of these pots were coated with slaked lime. 
The lime used in the collection of sweet toddy was removed initially by sedimentation and later by precipitation as calcium phosphate by adding superphosphate. Precipitation was enhanced by heating to about $40-50^{\circ} \mathrm{C}$ and by centrifugation. This centrifuged, decalcified sweet toddy was a clear, colourless liquid with a $\mathrm{pH}$ around $6.5-7$. This was sterilized by autoclaving at $15 \mathrm{lb} /$ in $^{2}$ pressure $\left(121^{\circ} \mathrm{C}\right)$ for 15 minutes.

\subsubsection{Fermented toddy}

This was obtained by collecting the palmyrah sap in earthenware pots by adopting the traditional process of toddy collection. Usually the samples were obtained in mornings after a collection period of about 14 hours.

\subsubsection{Peptone-yeast extract-sugar medium}

$\begin{array}{ll}\text { Peptone } & 3.0 \mathrm{~g} / 1 \\ \text { Yeast extract } & 5.0 \mathrm{~g} / 1 \\ \text { defined amount } \\ \text { Glucose \&/or sucrose } & 25.0 \mathrm{~g} / 1 \\ \text { Agar (if necessary) } & \end{array}$

This medium was sterilized by autoclaving at $15 \mathrm{lb} / \mathrm{in}^{2}$ pressure for 15 minutes.

\subsection{Collection and Preparation of Yeast Cultures}

Four different yeasts, viz., Saccharomyces cerevisiae PY 1, Kloeckera apiculata PY 2, Schizosaccharomyces pombe PY 7 and Saccharomyces chevalieri PY 10 , were isolated from the naturally fermented palmyrah toddy. ${ }^{11}$ These isolates were transferred into peptone-yeast extract-glucose $(4 \% \mathrm{w} / \mathrm{v})$-agar slopes and stored at $4^{\circ} \mathrm{C}$.

A loopful of the culture in need was transferred into $100 \mathrm{ml}$ portion(s) of sterile peptone-yeast extract-glucose $(2 \% \mathrm{w} / \mathrm{v})$ broth and was allowed to grow for 12 hours; then the sedimented yeast mass was separated by centrifugation, washed well with sterile water and appropriately diluted with sterile $0.85 \%(w / v)$ saline. This was used as the starter culture for the experiments.

\subsection{Methods}

\subsubsection{Routine analytical methods}

Amount of sugar in a sample was estimated according to the Somogyi's semimicro method. ${ }^{3}$ Alcohol content was determined using an ebulliometer or by the specific gravity method. ${ }^{6}$ 
Yeast cell count was estimated using a haemocytometer and the $\mathrm{pH}$ of the medium was determined using a Phillips PW $9418 \mathrm{pH}$ meter.

\subsubsection{Experimental procedures}

(a) Alcohol content of naturally fermented palmyrah toddy and the efficiency of the natural fermentation process.

The alcohol content of representative samples of palmyrah toddy collected from different parts of the Jaffna-peninsula was determined after 48 hours of fermentation. Similarly, the sugar content of fresh, unfermented sap. samples obtained from the male and female inflorescences of the palmyrah palm was determined by the routine method. The efficiency of the natural fermentation process was calculated on the basis of sucrose to alcohol conversion. About 15 samples of toddy were analysed under each of the different methods of tapping and the results were statistically analysed according to Bailey ${ }^{5}$ and are presented in Table 1.

Table 1. Alcohol content of naturally fermented palmyrah toddy and the efficiency of fermentation.

\begin{tabular}{|c|c|c|c|c|}
\hline $\begin{array}{l}\text { Method of tapping } \\
\& \text { inflorescence }\end{array}$ & $\begin{array}{l}\text { Mean sugar } \\
\text { content of } \\
\text { sap } \% w / v\end{array}$ & $\begin{array}{l}\text { Expected } \\
\text { alcohol } \\
\text { content } \\
\% \mathrm{v} / \mathrm{v}\end{array}$ & $\begin{array}{l}\text { Observed } \\
\text { alcohol } \\
\text { content } \\
\% \mathrm{v} / \mathrm{v}\end{array}$ & $\begin{array}{l}\text { Efficiency } \\
\text { of fermen- } \\
\text { tation }\end{array}$ \\
\hline${ }^{3}$ & & & & \\
\hline $\begin{array}{l}\text { 'Aripanai' - } \\
\text { young male }\end{array}$ & $12.94 p$ & 8.9 & $5.28 \mathrm{a}$ & $59 \%$ \\
\hline $\begin{array}{l}\text { 'Vallupanai' - } \\
\text { matured male }\end{array}$ & $13.33 \mathrm{p}$ & 9.19 & $5.53 \mathrm{a}$ & $60 \%$ \\
\hline $\begin{array}{l}\text { 'Thattupanai' - } \\
\text { young female }\end{array}$ & $15.15 \mathrm{q}$ & 10.45 & $5.67 \mathrm{a}$ & $54 \%$ \\
\hline $\begin{array}{l}\text { 'Kaivetty' } \\
\text { matured female }\end{array}$ & 10.89 r & 7.52 & $6.54 \mathrm{~b}$ & $87 \%$ \\
\hline
\end{tabular}

The values denoted by the different letters $p ; q \& \mathrm{r}$ and a $\&$ b are statistically different at $5 \%$ level $(\mathrm{p}<0.05)$.

Number of experiments: 15 for each method of tapping. 
(b) The fermenting abilities of the isolated yeast and bacterial strains:

The alcohol production by the yeasts mentioned in 2.2 was estimated by separately introducing an innoculum of $10^{5}$ cell $/ \mathrm{ml}$ of each yeast isolate into

(i) $100 \mathrm{ml}$ portions of palmyrah sweet toddy medium (denoted as PST)

(ii) $100 \mathrm{ml}$ portions of peptone-yeast extract broth having $14 \% \mathrm{w} / \mathrm{v}$ sucrose and $1 \% \mathrm{w} / \mathrm{v}$ glucose (denoted as DF).

The alcohol content in each case was determined using the ebulliometer after 24,48 and 72 hours of fermentation. As the sugar content of the two media employed differ, the efficiencies of alcohol production by these different yeast isolates can be compared. The maximum alcohol produced by these yeast isolates and their fermentation efficiencies are presented in Table 2.

Table 2. Maximum alcohol production and efficiency of fermentation of the different yeast isolates.

\begin{tabular}{|c|c|c|c|c|}
\hline \multirow[b]{2}{*}{ Yeast } & \multicolumn{2}{|c|}{$\begin{array}{l}\text { Maximum alcohol } \\
\text { content } \% \mathrm{v} / \mathrm{v}\end{array}$} & \multicolumn{2}{|c|}{$\begin{array}{l}\text { Efficiency } \\
\text { of fermentation }\end{array}$} \\
\hline & PST & DF & PST & DF \\
\hline Saccharomyces cerevisiae PY 1 & 8.3 & 8.0 & $92.29 \%$ & $77.56 \%$ \\
\hline Kloeckera apiculata PY 2 & 0.0 & 0.32 & $0.0 \%$ & $3.10 \%$ \\
\hline Scbizosaccharomyces pombe PY 7 & 7.85 & 8.0 & $91.07 \%$ & $77.56 \%$ \\
\hline Saccharomyces chevalieri PY 10 & 8.0 & $7: 5$ & $92.81 \%$ & $72.71 \%$ \\
\hline
\end{tabular}

PST $=$ Palmyrah Sweet Toddy medium

DF = Defined medium (peptone-yeast extract-sugar medium)

2.3.3 Microbial and Biochemical changes during natural fermentation of palmyrah toddy.

A new, clean clay pot was tied to the palmyrah inflorescence in the evening about 5 p.m. and the sap which dripped from the young female inflorescence into the pot was collected at about $6 \mathrm{a}$.m. on the following morning. Total and reducing sugar contents, alcohol content, yeast cell number and $\mathrm{pH}$ were determined periodically and the results are presented in Figure 1. 
Total sugar content $\% w / v$

- Reducing sugar content $\% \mathrm{w} / \mathrm{v}$

$\mathrm{O}-\mathrm{O}$ Alcohol content $\% \mathrm{v} / \mathrm{v}$

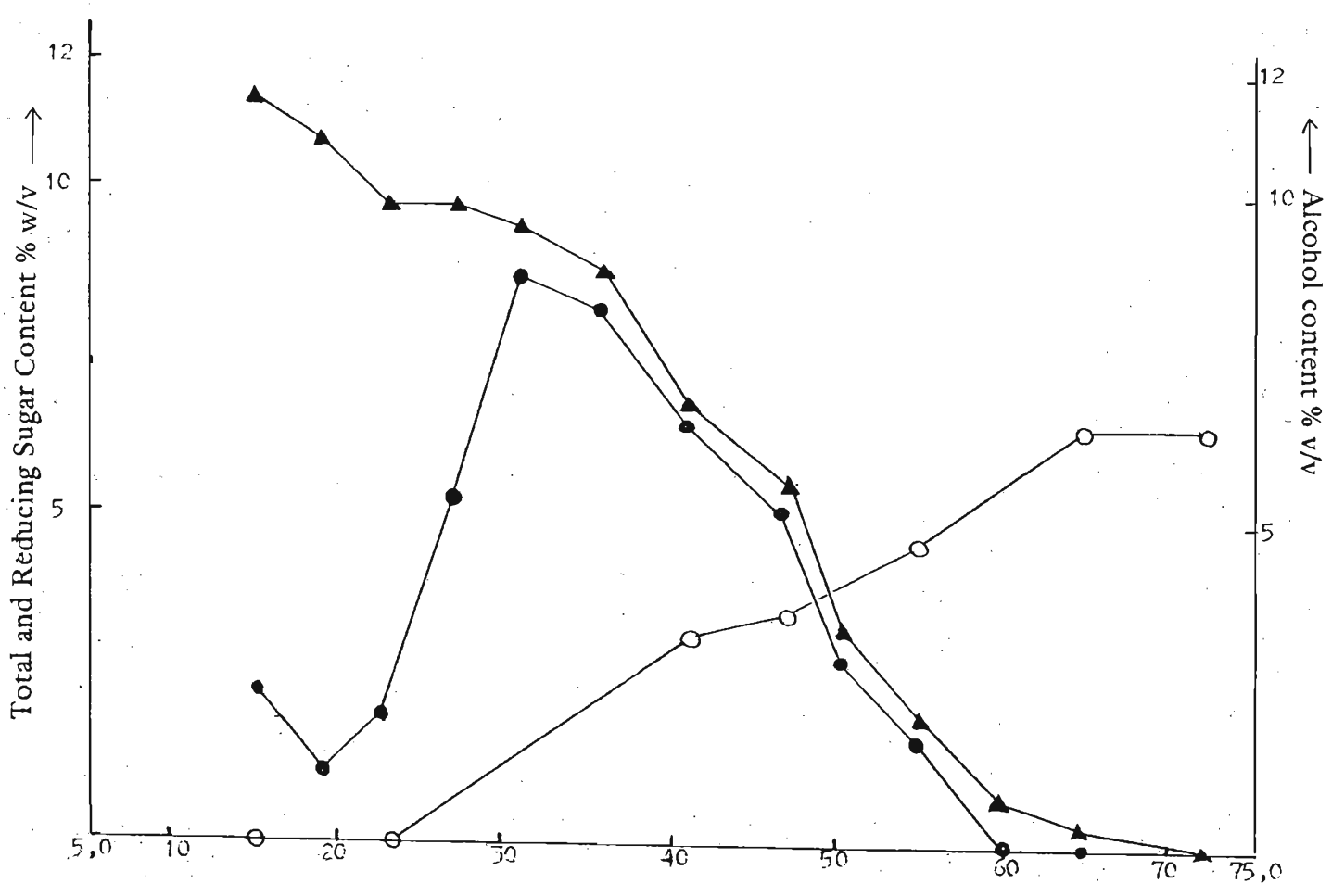

Duration of fermentation (hours) $\longrightarrow$

Figure 1. Changes in alcohol content and sugar content during natural fermentation of palmyrah toddy. 


\section{Results and Discussion}

3.1 Alcohol content of naturally fermented palmyrah toddy and the efficiency of the natural fermentation process

The results (Table 1) showed that the alcohol content of toddy samples collected towards the latter part of the tapping season from matured female inflorescences by the 'kaivetty' method of tapping was significantly more than in the samples obtained by the other three methods of tapping. Contrary to the earlier supposition that the sugar content of sap from matured female inflorescences would be high by comparison, an analysis of total sugar content in unfermented sap obtained by the 'kaivetty' method of tapping indicated that it is significantly lower than the sugar content in saps obtained by the other tapping methods.

As for the conversion of total sugar to alcohol, the toddy obtained from the matured female inflorescences had the highest efficiency of fermentation of about $87 \%$, whereas the efficiency of fermentation in toddy samples obtained by the other three methods of tapping was in the range of $50-60 \%$.

This lower efficiency of alcoholic fermentation was anticipated because of the presence of a mixed flora of yeasts and bacteria. The formation of several by-products and the conversion of about $1-2 \%$ of the sugars into yeast cell mass also accounts for the low yields of alcohol. In addition, some alcohol may get lost to the environment by entrainment in the carbondioxide, and by evaporation.

In spite of the lower sugar content of the sap, the matured female inflorescences produced toddy samples with higher alcohol contents, clearly indicating that the fermentation process was more efficient in sap derived from matured female inflorescences. This may be due to some difference in the microflora, which, in turn, may be affected by the climate and the composition of the sap. The 'kaivetty' method of tapping is employed at the stage when the female flowers have been fertilized. Gonsequently the sugars directed to these inflorescences may have been converted into other fermentable substances such as glucosides, amides or aminoacids, for possible use in the processes of fruit maturation and germination. As further development of the fruit is hindered by the tapping process, these substances may yield alcohol by undergoing fermentation. This hypothesis has yet to be supported by further experimental evidence. Also, it may be possible that this variation in sap composition may favour the presence and growth of highly fermentative yeast strains in sap from the matured female inflorescences of the palmyrah palm. 
This fermentation process can be improved under controlled conditions using pure yeast cultures on unfermented sap extracted from the palmyrah inflorescences.

\subsection{The fermenting abilities of the isolated yeast and bacterial strains}

The results presented in Table 2 indicate that as a general rule, the yeasts isolated from palmyrah toddy ferment and produce alcohol more efficiently in the palmyrah sweet toddy medium than in the defined medium. This may be accounted for by the different compositions of the media; these yeasts, by a process of natural selection over a long period of time, would have adapted to the prevailing environmental and nutritional conditions. The palmyrah palm sap may consist of some additional vitamins and aminoacids which favour the growth of these yeasts and thus enhance alcohol produc-
tion by them.

The lemon-shaped yeast Kloeckera apiculata (PY 2) is incapable of utilizing sucrose either fermentatively or oxidatively. Therefore, the relatively low amounts of reducing sugars in the media $(1.4375 \% \mathrm{w} / \mathrm{v}$ and $1 \%$ $\mathrm{w} / \mathrm{v}$ in palmyrah sweet toddy medium and defined medium respectively) would have been used by this particular yeast for the increase in biomass. Hence, there would not be appreciable quantities of reducing sugars left in these media so that they can be fermented by this yeast to produce alcohol.

These studies reveal that the Saccharomyces yeasts PY 1 and PY 10 are the best fermentors among those isolated from naturally fermented palmyrah toddy samples. Though the fission yeast Schizosaccharomyces pombe PY 7 produced equal quantities of alcohol, the maximum alcohol was obtained after a longer duration of fermentation. This must be attributed to the slower rate of growth of these fission yeasts.

Similar studies were carried out by inoculating palmyrah sweet toddy medium with Bacillus sphaericus B 2 , Bacillus cereus $B$ and Bacillus firmus $\mathbf{B} 17$, all of which were previously isolated from naturally fermented palmyrah toddy. The $\mathrm{pH}$ and sugar content of the media were estimated periodically. The results revealed that the presence of bacteria does not significantly affect the $\mathrm{pH}$ of the palmyrah toddy but they do utilize a small portion of the reducing sugars present in the medium. It was also found that the growth of these bacteria is somewhat suppressed in media having a $\mathrm{pH}$ less than 6.0 at the time of inoculation. The naturally fermented palmyrah wine has a $\mathrm{pH}$ in the range of $3.8-4.2$, which suggests that bacterial contamination and growth take place in the early stages of fermentation. When fresh unfermented palmyrah sap or decalcified, neutral sweet toddy is exposed to the air, the sap or medium becomes turbid and milky in appearance. This is due to the contamination of these media by large 
numbers of bacteria prior to the appearance of yeasts in these samples. The yeasts prefer an acidic medium for growth. The bacteria impart a whitish colour to the palmyrah toddy and may also contribute to its aroma and flavour.

All these bacteria require some aminoacids and vitamins for their growth and may utilize the aminoacids and vitamins found in palmyrah sap thus reducing the nutritive value of toddy formed as a result of the spontaneous fermentation. Also, these bacteria may secrete extracellular substances affecting the growth of yeast and, hence, alcohol production.

3.3 Microbial and Biochemical changes during natural fermentation of palmyrah toddy

The results presented in Figure 1 clearly indicate that the initial step in the alcoholic fermentation process is the hydrolysis of sucrose to reducing sugars. Ethanol production seems to begin only after the formation of appreciable quantities of reducing sugars. The maximum alcohol produced was $6.4 \% \mathrm{v} / \mathrm{v}$ and the $\mathrm{pH}$ dropped from 4.4 (after 15 hours of fermentation) to 3.9 after 72 hours of fermentation.

Saccharomyces yeasts were the predominant occupants of natural palmyrah toddy with varying amounts of Schizosaccharomyces. Yeasts belonging to the genus. Kloeckera were observed in the sample at the initial stages of fermentation, but the Saccharomyces yeasts overgrew them during the course of fermentation. This observation agrees with those reported by Reed and Peppler ${ }^{8}$ and Atputharajah et al. ${ }^{4}$ This domination of the Saccharomyces yeasts may be due to their superior fermentative ability.

It was observed that alcohol production started only after cell density reached its maximum. i.e., the fermentation process followed the growth phase of the yeasts. Therefore, it may be suggested that if a higher density of yeast cells is inoculated, not much sugar will be utilized by the yeasts for their growth and reproduction and most of the sugars in the medium will be converted into alcohol thus increasing the efficiency of fermentation.

These sets of experiments reveal that the efficiency of the fermentation process increases with the use of pure yeast innoculum. However, some other factors, for example, the addition of nutrients, may influence the production of alcohol. Therefore, further experiments are necessary to determine the optimal conditions for maximum production of alcohol from palmyrah sap. 


\section{Acknowleugement}

We thank the Natural Resources, Energy and Science Authority of Sri Lanka (NARESA) and the International Foundation for Science (IFS), Sweden for their generous financial assistance under the grants RG/83/19 and $581 / \mathrm{E}$ respectively.

\section{References}

1. AMERINE, M.A. (1958) Composition of wines II: Inorganic constituents. Adv. in Fd. Res. $8: 135-200$.

2. AMERINE, M.A., BERG, H.W. \& CRUESS, W.V. (1972) The technology of wine making. p. 177-244. The AVI publishing Company, U.S.A.

3. AOAC (1960) Official Metbods of Analysis 9th Edition. p. 421 Washington, D.C. Assn. of Official Agric. Chemists.

4. ATPUTHARAJAH, J.D., SAMARAJEEWA, U. \& VIDANAPATHIRANA, G.S. (1980) Lactic-alcoholic fermentation in coconut toddy, Proc. Sri Lanka Assn. Adv. Sci. 36(1): 58 (abstract).

5. BAILEY, N.T.J. (1959) Statistical Methods in Biology. Hodder \& Stoughton, London.

6. CHRYSTOPHER, R.K (1985) Studies on the fermentation of Borassus flabellifer palmyrah palm sap. M. Phil. Thesis, University of Jaffna, Sri Lanka.

7. LAMPEN, J.O. (1968) Antonie van Leeuwenboek 34, 1-18 Cited in Kalyananda, M.K.G.S. (1978) - Some aspects of the fermentation of coconut toddy. M. Phil Thesis, University of Colombo, Sri Lanka.

8. REED, G. \& PEPPLER, H.J. (1973) Wine yeasts in reast Tecbnology. The AVI publishing Company, U.S.A. p. $165-215$.

9. THEIVENDIRARAJAH, K. \& CHRYSTYPHER, R.K, (1983) Studies on palmyrah (Barassus flabellifer) palm sap, Proc. Sri Lanka Assn. Adv. Sci. 39(1): 64 (abstract),

10. THEIVENDIRARAJAH, K. \& CHRYSTOPHER, R.K. (1984) Studies on the microbial fermentation of palmyrah (Borassus flabellifer) palm sap. Proc. Sri Lanka Assn. Adv. Sci 40(1): 53 (abstract). 
11. THEIVENDIRARAJAH, K. \& CHRYSTOPHER, R.K. (1985) Microflora of fermented palmyrah (Borassus flabellifer) palm sap, $7 \mathrm{tb}$ International Conference on the Global Impacts of Applied Microbiology (GIAM VII), Helsinki, Finland. 12-16 August, 1985 (abstract).

12. THIRUKANESAN, A. \& THEIVENDIRARAJAH, K. (1987) Methods used in tapping palmyrah palm (Borassus flabellifer Linn.), Pbyta 1(3): 25-29. 